軽金属 第52巻 第 9 号 (2002)，410-416

\title{
熱処理に伴ら高純度アルミニウム中鉛の表面偏析
}

\author{
椿野 晴繁* ·野上 敦司** ·寺澤 倫孝* · 三田村 徹* \\ 山ノ井智明 $* * *$. 木野村 淳**** . 堀野 裕治****
}

Journal of Japan Institute of Light Metals, Vol. 52, No. 9 (2002), pp. 410-416

\section{Surface segregation of lead in high-purity aluminum during heat treatment}

\author{
Harushige TSUBAKINO* Atsushi NOGAMI**, Mititaka TERASAWA*, Toru MITAMURA* \\ Tomoaki YAMANOI***, Atsushi KINOMURA**** and Yuji HORINO****
}

\begin{abstract}
The surface segregation of lead in the high-purity aluminum foils containing a small amount of lead annealed at various conditions was studied by Rutherford back scattering spectroscopy (RBS) and transmission electron microscopy (TEM). The foils containing 0.13 and 13 at-ppm Pb were annealed for $1.8 \sim 72 \mathrm{ks}$ at $473 \sim 923 \mathrm{~K}$. The annealing at higher temperature and for longer time enhanced segregation of the lead at foil surface region, but TEM-EDS revealed that most of the lead segregated not to the aluminum surface but to the oxide film formed by heat treatment. The oxide film was amorphous phase in all the heat-treated foils. The oxide compositions ranged from 20 to $50 \mathrm{at} \% \mathrm{~Pb}$, from 10 to $50 \mathrm{at} \% \mathrm{O}$ and remained $\mathrm{Al}$ depending on the position. The surface segregation process was discussed.
\end{abstract}

(Received January 18, 2002)

Keywords: lead, surface segregation, oxide film, RBS, TEM

\section{1. 緒 言}

電解コンデンサ用高純度アルミニウム箔はエッチングを施 し静電容量を増大して使用されている。そのため，箔のエッ チング過程や垂直エッチピット形成条件と微量添加元素の関 係などについて，近年盛んに調べられている1)。垂直ェッチ ピット形成には, 䈃に微量添加されている種々の元素の内, 鉛，すず，ビスマス，鉄などが影響していることが明らかに なってきた ${ }^{2), 3)}$ 。その中でも鉛の添加は，コンデンサの静電 容量増大への寄与が大きいことから，エッチピットの形成能 には鉛の䇤表面への偏析が影響していることが最近明らかに されつつある(4) 8)。不純物元素の表面偏析現象は，エッチピ ット形成能のみならず工業的な観点において種々の影響を及 ぼす1)ので, 表面偏析現象を解明する必要があるが, 表面偏 析は粒界偏析に比べてまだデータの少ない分野である。

$\mathrm{Lin}^{4)}$ らは，2 次イオン質量分析法（SIMS）を用いて，焼 なまし市販アルミニウム箔（＜2 mass-ppm Pb）の表面から 30〜 $50 \mathrm{~nm}$ に鉛の表面偏析を認めた。名取ら 5 も SIMS で $\mathrm{Al}$ -0.7 扰よび $1.5 \mathrm{ppm} \mathrm{Pb}$ 管の表面への鉛の濃縮を確認した。 Aloni ら ${ }^{6)}$ はオージェ分析によって Al-100 at-ppm Pb 筞を823 Kで焼なますと $55 \%$ もの鉛が表面濃縮することを報告し
た。また SIMS とラザフォード後方散乱法 (RBS)を用いて, Ashitaka ら 7 は銅を最大 $100 \mathrm{ppm}$ 抢よび鉛を $1.5 \mathrm{ppm}$ 含むア ルミニウム箟に打ける鉛の表面濃縮を検討し, 銅濃縮は顕著 でないが鉛濃縮は著しく，乙か子酸化皮膜直下の約 $1 \sim 2 \mathrm{~nm}$ に鉛が濃縮していると推測した。藤井ら ${ }^{8)}$ も酸化皮膜直下に 鉛が濃縮すると考えているし, さらに, 透過電子顕微鏡 (TEM) 観察により表面偏析した鉛は結晶性酸化物（ $\mathrm{PbAl}_{12}$ $\mathrm{O}_{19}$ ）となっているとする川井ら ${ }^{9)}$ の研究報告もある。我々

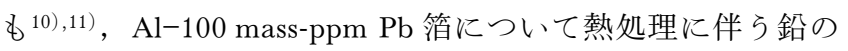
表面偏析現象をRBS と TEM 観察で調べ, 表面偏析の鉛以 外に微細な多角形鉛粒子の存在を明らかにした。しかし, 鉛 の偏析位置を含め表面偏析状態などの情報は依然不明である。

本研究では, $\mathrm{Al}-0.13$ at-ppm (1 mass-ppm) Pb 㧊よび 13 at-ppm (100 mass-ppm) Pb のアルミニウム箔に種々の熱処 理を施し, それに伴う鉛の表面偏析をRBS, TEM 観察执よ び TEM-EDS（エネルギー分散型分光）分析で偏析鉛の存 在状態を明らかにすることを目的とした。

\section{2. 実験方法}

高純度アルミニウム（99.999\%）と粒状鉛（99.99\%）か ら, 厚さ $40 \mathrm{~mm}$ の $\mathrm{Pb}$ 組成が 0.13 at-ppm と 13 at-ppm (以後,

* 姫路工業大学大学院工学研究科物質系工学専攻（勇671-2201 兵庫県姫路市書写2167)。Division of Materials Science and Engineering, Graduate School of Engineering, Himeji Institute of Technology (2167 Shosha, Himeji-shi, Hyogo 671-2201).

E-mail: tubakino@mse.eng.himeji-tech.ac.jp

** 姫路工業大学大学院生 (姫路市)。Graduate Student, Himeji Institute of Technology (Himeji-shi, Hyogo).

**** 昭和電工秼アルミニウム技術研究センター (小山市)。Showa Denko K.K. (Oyama-shi, Tochigi).

**** 独立行政法人産業技術総合研究所関西センター (池田市)。National Institute of Advanced Industrial Science and Technology KANSAI (Ikeda-shi, Osaka). 
Table 1 Chemical compositions of high-purity $\mathrm{Al}-\mathrm{Pb}$ foils (at-ppm)

\begin{tabular}{c|c|c|c|c|c|c|c|c}
\hline \hline Foil & $\mathrm{Pb}$ & $\mathrm{Si}$ & $\mathrm{Fe}$ & $\mathrm{Cu}$ & $\mathrm{Mn}$ & $\mathrm{Gr}$ & $\mathrm{Zn}$ & $\mathrm{Ni}$ \\
\hline $0.13 \mathrm{ppmPb}$ & 0.13 & $<1$ & $<0.1$ & $<0.4$ & $\mathrm{ND}$ & $\mathrm{ND}$ & $\mathrm{ND}$ & $<0.5$ \\
$13 \mathrm{ppmPb}$ & 13 & 4 & 2 & $<1$ & $<1$ & $<1$ & $<1$ & $<1$ \\
\hline
\end{tabular}

ND: not detected

単に ppm と表示する）の 2 種類の鋳塊を作成した。これを $35 \mathrm{~mm}$ に面削した後，アルゴン気流中で883 K, $72 \mathrm{ks}$ の均一 化焼なましを施した。それを熱間圧延で $8 \mathrm{~mm}$ 板に加工後酸 洗し，さらに数回の冷間圧延で $0.1 \mathrm{~mm}$ 厚の䈃に仕上げた。 䈃の化学組成を Table 1 亿示す。䈃を約 $10 \times 20 \mathrm{~mm}^{2}$ に切断 し，出発条件を整えるためいったん両表面を各々約 $1 \mu \mathrm{m}$ 泀 ぞ電解研磨した。その後, 次に示す等温熱処理をアルゴン気 流中で施した。すなわち, $\mathrm{Al}-13 \mathrm{ppm} \mathrm{Pb}$ 箔については473〜 $923 \mathrm{~K}$ で1.8〜 72 ks, Al-0.13 ppm Pb 雗は $813 \mathrm{~K}$ で3.6〜 $72 \mathrm{ks}$ である。比較として未熱処理材, すなわち電解研磨のみを施 した箔も用いた。な拈，電解研磨は， $60 \%$ 過塩素酸：エタ ノール $=1: 8$ の液を用い, 液温 $273 \mathrm{~K}$ で電圧 $8 \mathrm{~V}$ で行った。

それぞれの䈃について，ラザフォード後方散乱法（RBS） 測定拈よび透過電子顕微鏡（TEM）観察を行った。RBS 測 定は，前報10) と同様，約 $10 \times 10 \mathrm{~mm}^{2}$ に切断した箔に 1.8 $\mathrm{MeV}$ の $\mathrm{He}$ イオンを $20 \mu \mathrm{C}$ 照射し，散乱イオンの検出角度 は $165^{\circ}$ で行った。RBSの散乱スペクトルの解析方法も前 報10) と同様である。

TEM 観察用試片は，䇴を樹脂埋めした後ミクロトームで 䇴表面にほぼ垂直にカットして作製した。TEM 観察および EDS 分析は，JEM-2010電子顕微鏡を用いて行った。その加 速電圧は200 kVであった。

\section{3. 結果および考察}

\section{1 RBS 測定}

温度を $813 \mathrm{~K}$ 一定とし，種々の時間焼なました䇴の RBS 測定結果を Fig. 1 亿示す。未焼なまし䇴の測定結果も一緒 に示した。焼なまし䈱には，微弱な鉛と酸素の散乱ピークお よび明瞭なアルミニウムの立ち上がりが認められる。なお，

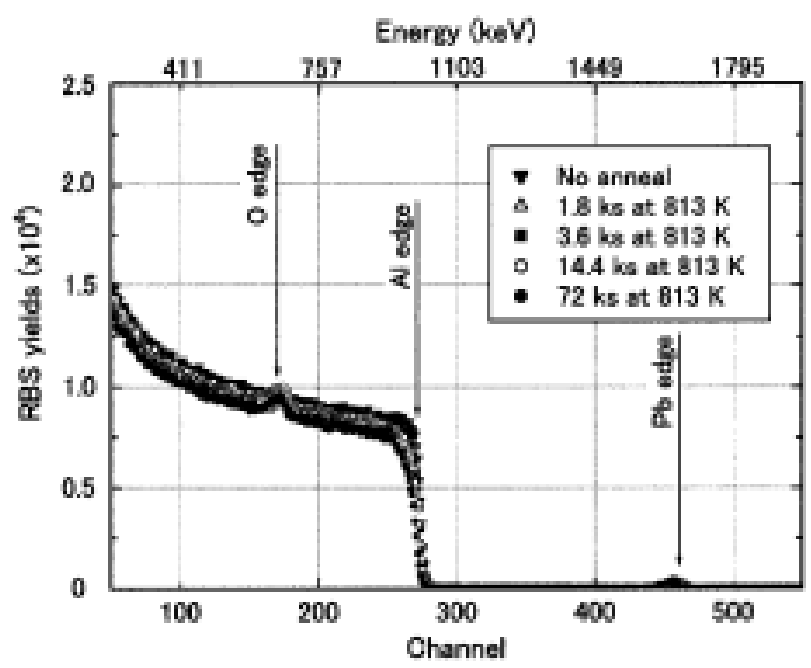

Fig. 1 RBS spectra of $\mathrm{Al}-13$ at-ppm $\mathrm{Pb}$ foil annealed at $813 \mathrm{~K}$ for various durations.

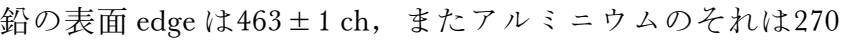
$\pm 1 \mathrm{ch}$ であった。本実験では，99.999\%鉛を99.999\%アルミ ニウム板に真空蒸着した標準試料を用いて，それらを評価し た。

Fig. 1 の鉛の散乱ピーク部分を拡大すると Fig. 2 のように なる。未焼なまし䇴には鉛の散乱強度は汪とんど認められな いが，焼なました䇴のそれはチャンネルの減少とともに急激 に立ち上がり，ピークを経てさらに低チャンネルで減衰す る。これより, 䈃表面に鉛が濃縮, すなわち表面偏析してい ることを確認できた。散乱強度のピーク高さは鉛の濃度に比 例する ${ }^{12)}$ ので，焼なまし時間の増加とともに鉛の偏析量が増 加することがわかる。さらに，長時間のもの汪ど，ピークが 低チャンネル側へ移行する傾向があり，散乱強度が減衰する 低チャンネル側をみるに，より低チャンネルまで散乱スペク トルが存在することがわかる。このことからより長時間焼な ますと，試料のより深い位置まで偏析鉛は存在していること が明らかとなった。RBS 測定の結果からバックグラウンド

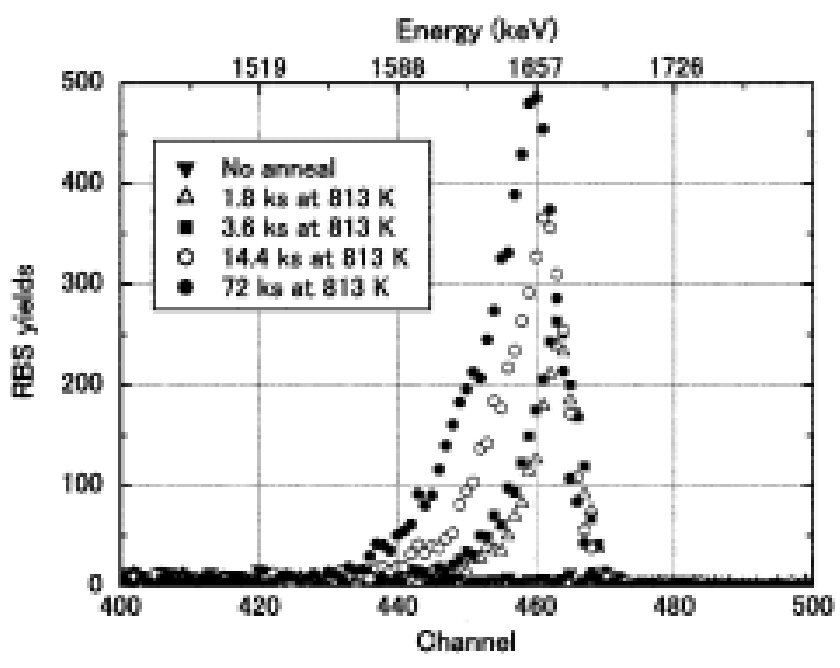

Fig. 2 Enlargement of lead spectra of Fig. 1.

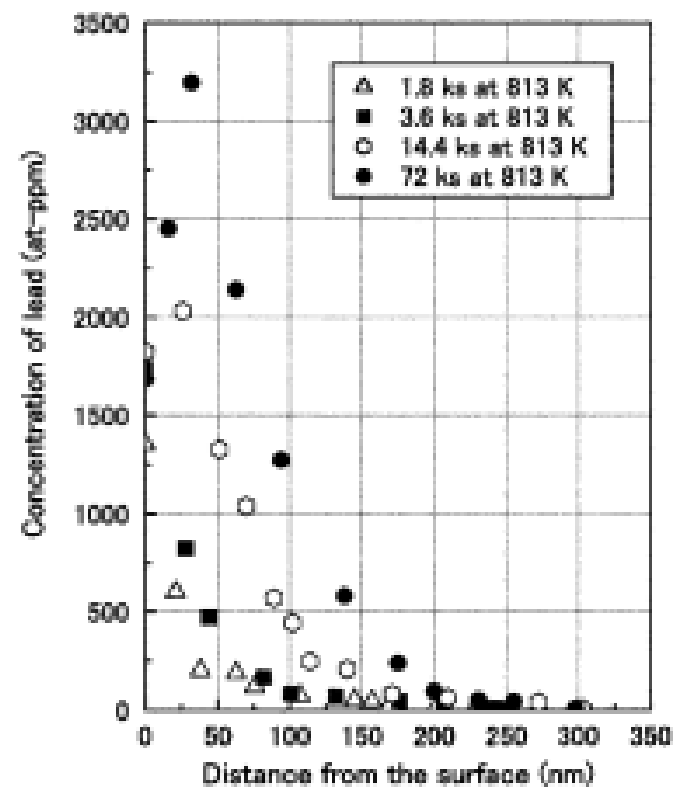

Fig. 3 Depth profile of lead concentration, estimated from RBS spectra of Fig. 2. 
の散乱強度を差し引いて, 深さ方向の鉛の濃度分布を前報 ${ }^{10)}$ と同様に評価した。その結果を Fig. 3 亿示す。短時間の焼 なまし簐に扣いては深さ方向に鉛濃度の単一減少を示すが， 長時間の場合は，深さ25 nm 前後の極浅い位置で鉛濃度の最 大值を示しさらに深くなると急激に鉛濃度は減少する。本 RBS 測定のエネルギー分解能 $(3.3 \mathrm{keV})$ からこれ以上の解 析点を得ることは困難であるので，この最大濃度を示す深さ の定量的信頼性は乏しいと考えられる。この点については, 今後さらに精度の高いRBS で検討する必要があるだろら。 偏析鉛の最大量は $1.8 \mathrm{ks}$ 焼なましで約 $1300 \mathrm{ppm}$ であるが， $72 \mathrm{ks}$ の場合は $3200 \mathrm{ppm}$ となり，焼なまし時間が増すとそれ は上昇した。この結果，焼なまし時間 $72 \mathrm{ks}$ での鉛の偏析度 $\left(C_{\mathrm{s}} / C_{\mathrm{b}}: C_{\mathrm{s}}\right.$ は表面近傍の最大濃度, $C_{\mathrm{b}}$ はバルク初期濃度) は，約250倍となった。また，200 $\mathrm{nm}$ 以上の深さには，鉊は 注とんど存在しないことも判明した。

さらに高温の $923 \mathrm{~K} て ゙$ 焼なました䇴の RBS 測定結果を

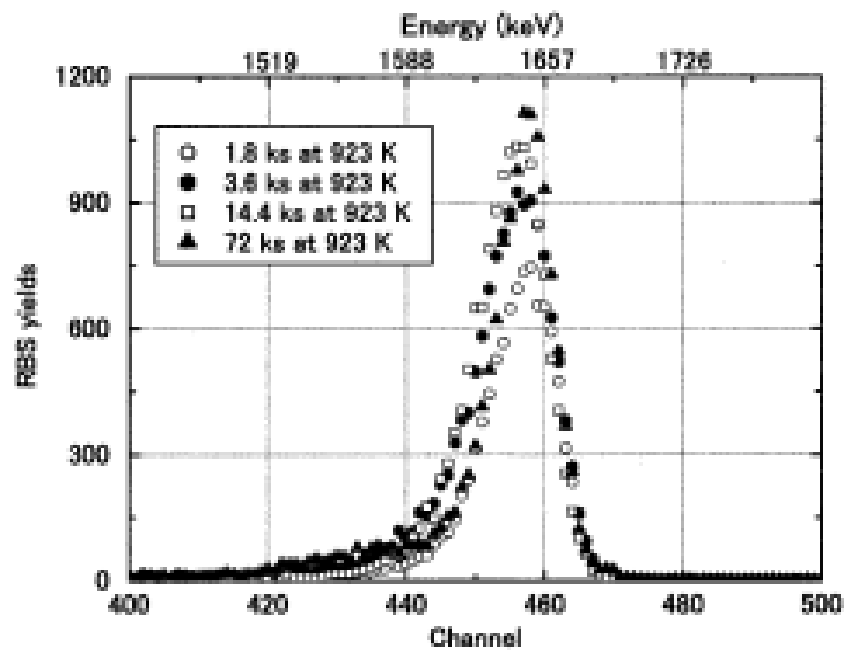

Fig. 4 Lead RBS spectra of $\mathrm{Al}-13$ at-ppm $\mathrm{Pb}$ foil annealed at $923 \mathrm{~K}$ for various durations.

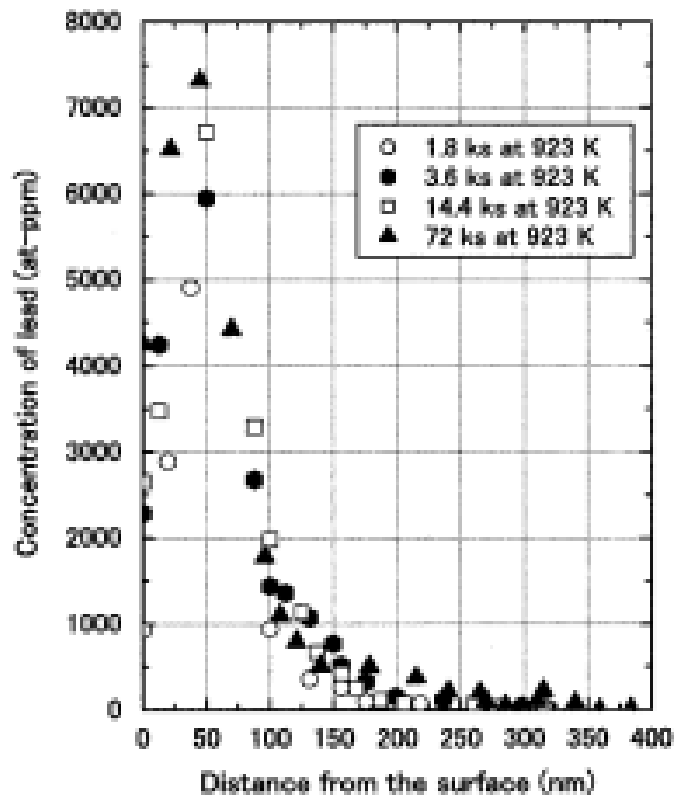

Fig. 5 Depth profile of lead concentration, estimated from RBS spectra of Fig. 4.
Fig. 4 亿示す。これより，高温焼なまし材に拈いても $813 \mathrm{~K}$ の場合と同様の表面偏析現象を示寸こと，および散乱ピーク が一層高くなることが示された。すなわち，高温で長時間の 焼なましを施せば，鉛はより多く表面偏析し，しかも表面よ りさらに深い位置まで偏析鉛が存在することが判明した。そ の深さ方向の鉛濃度プロファイルの解析結果を Fig. 5 に示 す。最も長時間の $72 \mathrm{ks}$ の場合は最大鉛量 $7300 \mathrm{ppm}$ となり, 偏析度は560倍に達した。また， $72 \mathrm{ks}$ 焼なましの場合は深さ 約 $250 \mathrm{~nm}$ 付近まで偏析鉛は存在するよらである。Fig. 3 と Fig. 5 を比較すると, 表面への鉛の偏析速度は時間よりもむ しろ温度に大きく依存するようである。表面偏析は，バルク 内の鉛が表面へ拡散することによって供給される挙動とみな される ${ }^{12)}$ 。その拡散速度はアルミニウム母相中鉛の拡散係数 (D) に依存し, さらに $D$ は温度とともに指数関数的に増加 するので，上の結果は合理的であろら。

偏析量の温度依存性を詳しく知るために, 保持時間を $72 \mathrm{ks}$ 一定とし，473 K から $923 \mathrm{~K}$ までの種々の温度で焼なま しを行い，その各焼なまし䇴について RBS 測定した。その 結果をFig. 6 に示す。な拈図中 $813 \mathrm{~K}$ と $923 \mathrm{~K}$ のデータは Fig. 2 と Fig. 4 に示したものである。 $473 \mathrm{~K}$ 焼なまし箔には 鉛の散乱スペクトルは法とんど認められず，573 K 焼なまし でわずかのスペクトルが認められるが，スペクトルが明瞭に 確認できるのは $673 \mathrm{~K}$ 以上といらことになる。これより，焼 なまし温度の上昇に伴い, 表面での鉛偏析量は増加すること が示された。この結果は, Aloni ら ${ }^{6)}$ の $823 \mathrm{~K}$ 焼なましで表 面偏析は完了寸るといら見解とは幾分異なるが，偏析の温度 依存性は彼らのデータに類似していた。しかし, 焼なまし温 度が上昇すると，ピーク位置は低チャンネル側へ移行し，よ り深い位置にまで偏析鉊が存在していることを本実験結果は 示している。

鉛含有量の少ない $\mathrm{Al}-0.13 \mathrm{ppm} \mathrm{Pb}$ 試料の RBS 測定結果を Fig. 7 抌よびFig. 8 に示す。焼なむし温度は $813 \mathrm{~K}$ である。 高濃度の $\mathrm{Al}-13 \mathrm{ppm} \mathrm{Pb}$ 箔の場合と同様な散乱鉛ピークが認 められた。また, 深さ $200 \mathrm{~nm}$ 以上では汪とんど偏析鉛は存 在しないことも高濃度䇴と同様である。72 ks の焼なましの 場合, 鉛の最大偏析量は約 $210 \mathrm{ppm}$ となり, 高濃度箔の場合 よりはるかに小さい。しかし，Fig. 7 扎よび Fig. 8 の結果か

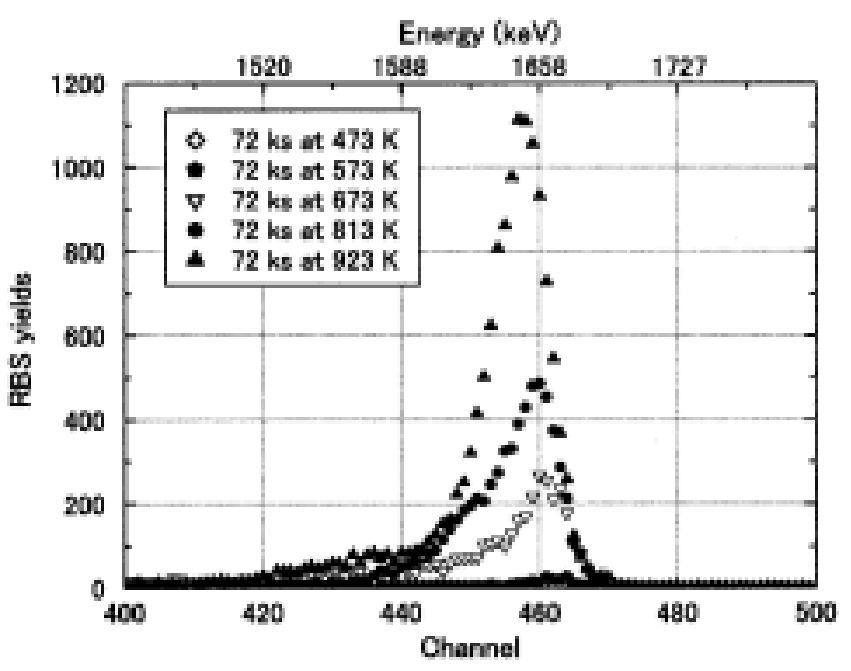

Fig. 6 Lead RBS spectra of $\mathrm{Al}-13$ at-ppm $\mathrm{Pb}$ foil annealed at various temperatures for $72 \mathrm{ks}$. 


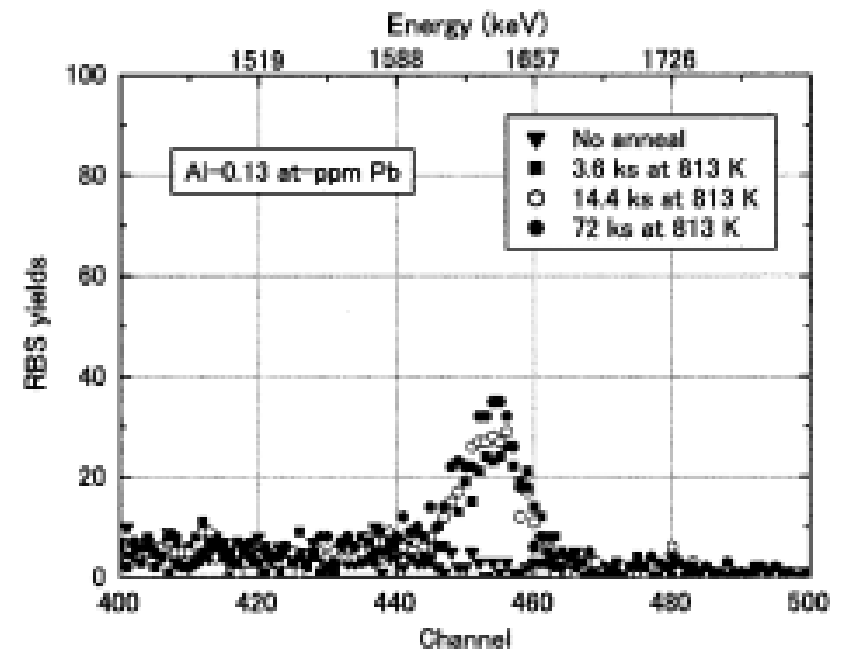

Fig. 7 Lead RBS spectra of $\mathrm{Al}-0.13$ at-ppm $\mathrm{Pb}$ foil annealed at $813 \mathrm{~K}$ for various durations.

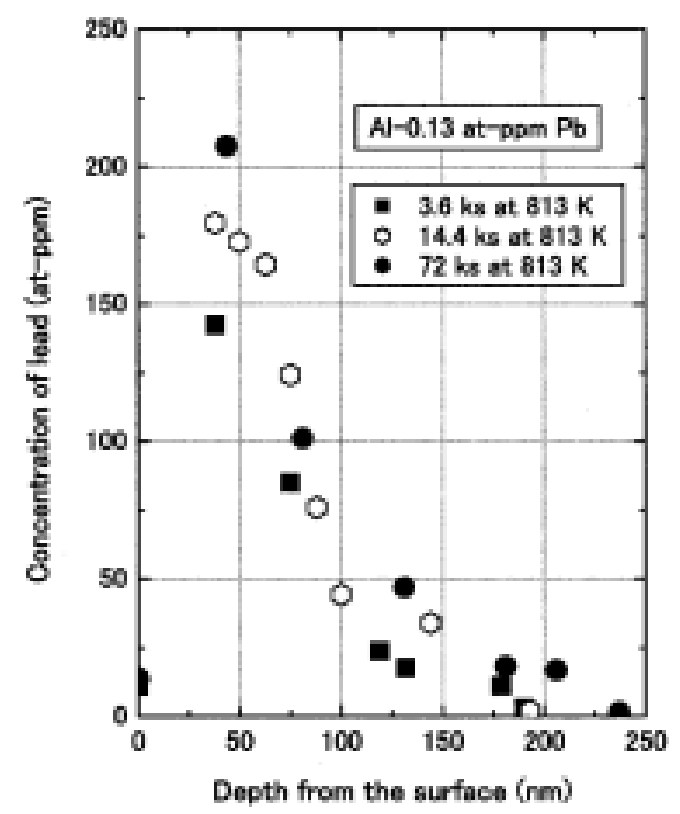

Fig. 8 Depth profile of lead concentration, estimated from RBS spectra of Fig. 7.

ら, 低濃度箔の表面偏析挙動は, 高濃度箔の場合に極めて類 似していることが示された。

\subsection{TEM 観察および TEM-EDS 分析}

RBS 測定結果から，高温・長時間の焼なましに伴って簿 表面近傍に鉛がより多く偏析することが明らかになった。そ こで，偏析濃度の高かった $\mathrm{Al}-13 \mathrm{ppm} \mathrm{Pb}$ 䇴を用いて，鉛の 偏析の様子をさらに詳細調べるためTEM観察を行った。 Fig. 9 は， $813 \mathrm{~K} て ゙ 14.4 \mathrm{ks}$ 焼なました $\mathrm{Al}-13 \mathrm{ppm} \mathrm{Pb}$ 簿の TEM 観察結果の一例である。Fig. 9(a)，(b)飞示されるよう に，暗く観察されるアルミニウム母相の表面上に，やや明る く観察される酸化皮膜が生成していることがわかる。この酸 化皮膜は同一厚さでなく場所によって $30 \sim 300 \mathrm{~nm}$ 厚さと大 きく異なったが，比較的厚い皮膜が形成していた。これは， 本実験では炉内のアルゴンガス置換が不十分な状態で䇴表面 をアルゴンガス気流中に露出して熱処理したためであろう。

Fig. 9 (c)拈よび (d) そ示される母相および酸化皮膜の制限視

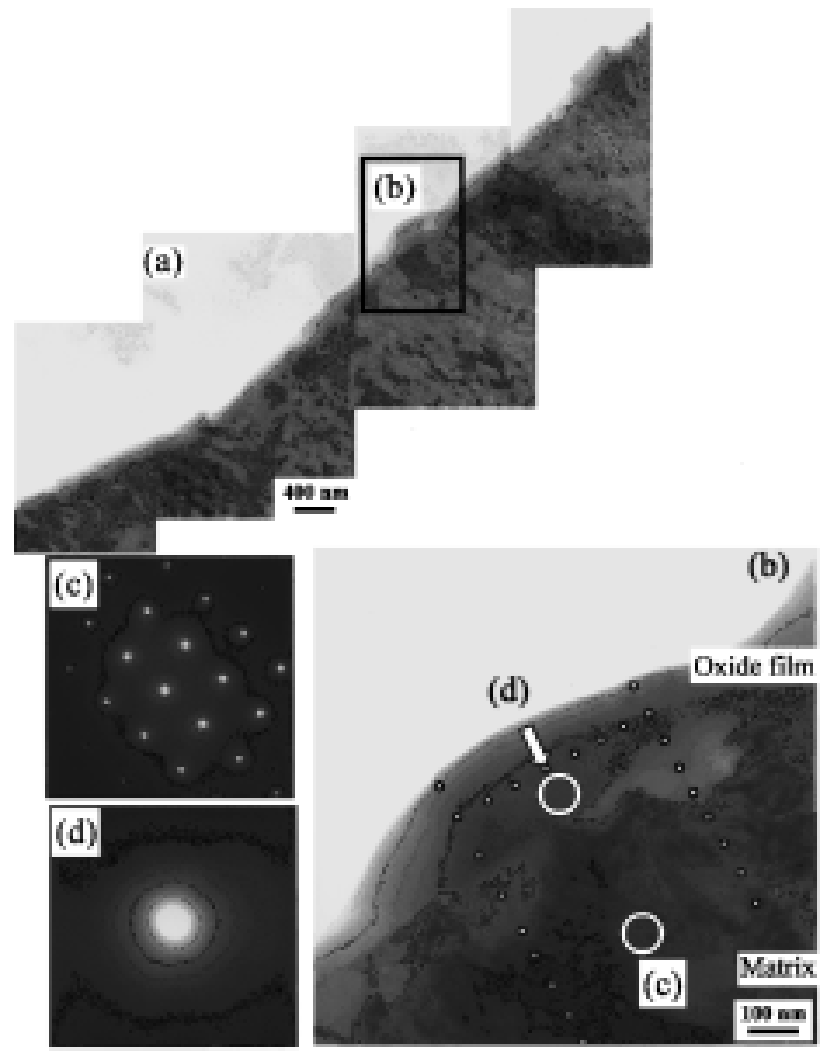

Fig. 9 TEM observations of $\mathrm{Al}-13$ at-ppm $\mathrm{Pb}$ foil annealed at $813 \mathrm{~K}$ for $14.4 \mathrm{ks}$, showing oxide film formed just above the surface of $\mathrm{Al}$ matrix. (a), (b) bright field image, (c) SADP of the matrix, $[110]_{\text {matrix }}$, (d) SADP of oxide film showing hallo-pattern.
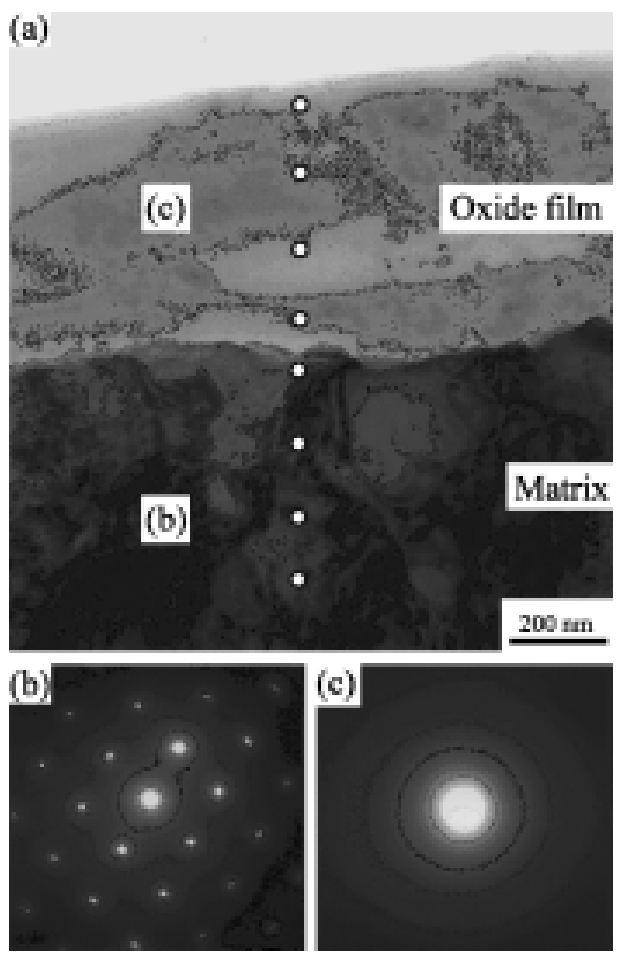

Fig. 10 TEM observations of $\mathrm{Al}-13$ at-ppm $\mathrm{Pb}$ foil annealed at $923 \mathrm{~K}$ for $72 \mathrm{ks}$. (a) bright field image, (b) SADP of Al matrix, (c) SADP of oxide film. 


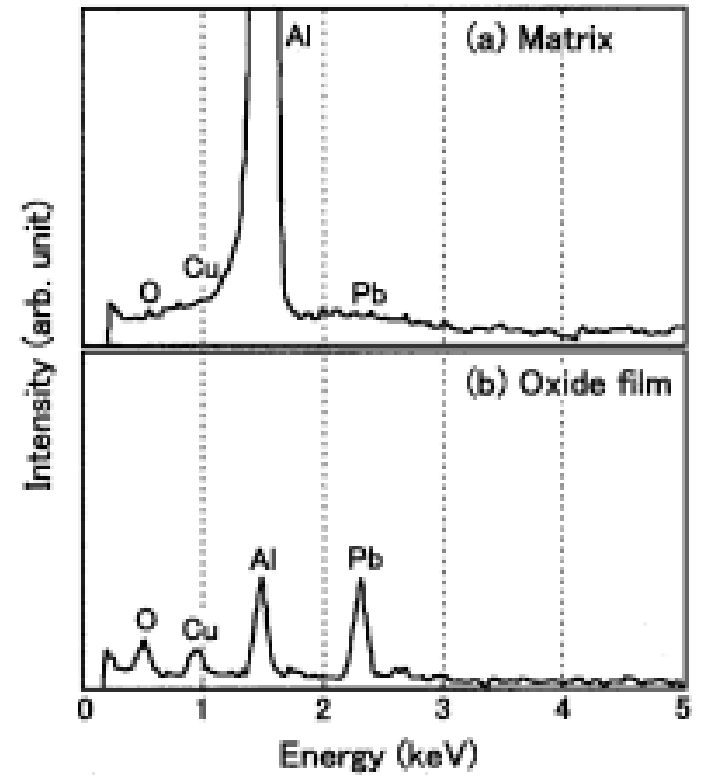

Fig. 11 Typical TEM-EDS spectra of Al-13 at-ppm $\mathrm{Pb}$ foil annealed at $813 \mathrm{~K}$ for $14.4 \mathrm{ks}$. (a) matrix, (b) oxide film.

野回折図形（SADP）によると，母相は110回折図形を示す のに対し，酸化皮膜のそれは八ローパターンを示した。さら にハローパターンの暗視野像より酸化皮膜の全域がアモルフ ァス構造一相から構成されていることも判明している。この ような結果は，さらに高温・長時間の $923 \mathrm{~K}$ で72 ks 焼なま した管の TEM 観察結果（Fig. 10）にも示された。Fig. 10 では酸化皮膜が約 $400 \mathrm{~nm}$ と著しく厚い箇所を示している が，その厚さは場所によって異なることを他の視野の TEM 観察で判明している。注目すべきことは，Fig. 10 (c) に示す よらに, このよらな高温の焼なましで形成した酸化皮膜もア モルファス相から構成されているといら点である。このよう な高温でアモルファス相が生成するといら結果は過去に報告 例がなく, 本研究で始めて示された新しい知見であり興味深 い。

Fig. 9 の母相と酸化皮膜に拈けるEDS 分析の一例をFig. 11 に示す。その際の分析の電子ビーム径は約 $5 \mathrm{~nm}$ であっ た。図中銅に相当するピークは, TEM 試片を銅製メッシュ ではさんで分析を行ったためである。Fig. 11より，母相ア ルミニウム中には鉛は汪とんど存在していないが，酸化皮膜 中に明瞭に鉛が存在することが示された。Fig. 9(b)の小さ い丸印に沿っての EDS 分析結果を Fig. 12に示す。位置によ って分析結果が異なるが，表面から深さ方向に濃度勾配を示 寸傾向があり，酸化皮膜からアルミニウム母相に移る深さ 200 300 nm 前後以上では鉛は検出されていない。この深さ は Fig. 3 の RBS の結果によく一致している。さらに䈃表面 に垂直な左右の測定列は約 $400 \mathrm{~nm}$ しか離れていないにもか かわらず，その濃度分布の形状はFig. 12(a)と（b)に示すよ らに異なった。しかし，いずれも鉛は酸化皮膜中にの及存在 し，アルミニウム母相や酸化皮膜/母相界面にはほとんど存 在しないことが本実験の分析結果で明らかになった。このよ らな鉛濃度測定の報告例は過去になく，新しい実験結果であ ろら。䇴表面に平行な方向の EDS 分析結果 (Fig. 12(c)) に よると，各元素の濃度は測定位置によって異なるが，鉛の濃
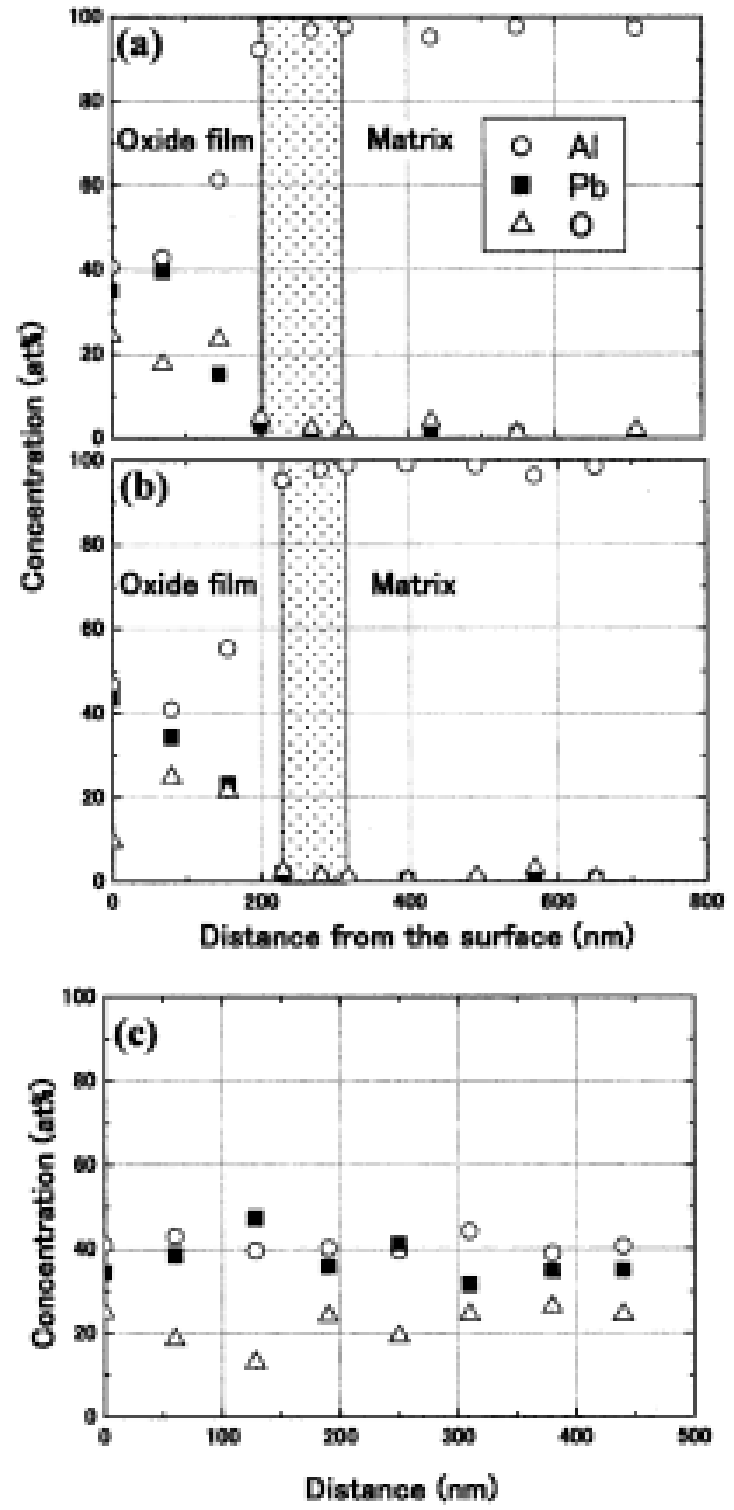

Fig. 12 Concentration profiles of $\mathrm{Al}, \mathrm{Pb}$ and $\mathrm{O}$ elements obtained from TEM-EDS along the lines of opened circles shown in Fig. 9. (a) depth profile along the left line, (b) depth profile along the right line, (c) profile along the parallel line to the foil surface.

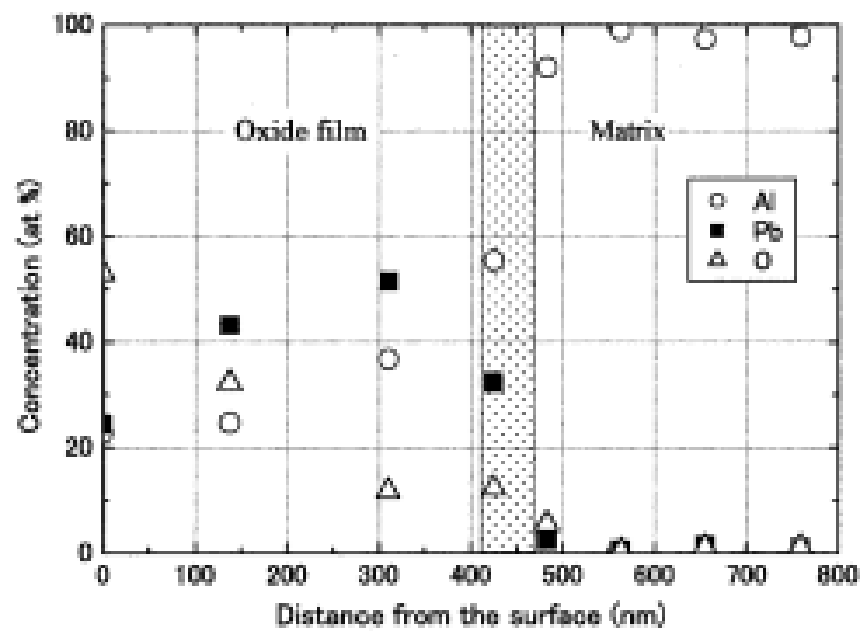

Fig. 13 Concentration profiles of $\mathrm{Al}, \mathrm{Pb}$ and $\mathrm{O}$ elements obtained from TEM-EDS along the line shown in Fig. 10 . 
度は大体30 50 at $\%$, 酸素*は20 at \% 前後，アルミニウムは 40 at \% 前後となり，化学量論的な固定組成は示さず，また 酸化皮膜中の鉛量は一定值でないよらである。Fig. 13は Fig. 10に示す丸印位置での分析結果である。この場合も， 鉛は酸化皮膜中にのみ存在し，アルミニウム表面すなわち酸 化皮膜/母相界面には鉛の濃縮はないことが再度明瞭に示さ れた。

Fig. 12拈よび Fig. 13の本実験結果は, Ashitaka 5 ${ }^{7)}$ や藤井 ら 8 による酸化皮膜/アルミニム母相界面に鉛が濃縮すると いら推測とはまったく異なることが示された。なお，TEM 像に, 酸化皮膜と母相が一部重なっている様子がうかがえ る。これは, 皮膜厚さが局所的に異なるためか，または䇴表 面に対し垂直でなくやや斜めにカットしたことが原因と考光 られる。そのため Fig. 12拈よび Fig. 13に拈いて，酸化皮膜 とアルミニウム母相との境界を幅で示した。Fig. 12拈よび Fig. 13の結果を比較すると, 高温の場合（Fig. 13）は, 酸 化皮膜の表面近傍の鉛量が少なく酸化皮膜内部へ行くに従い 鉊量が増加するといら点に違いがある。本研究の酸化皮膜中 の TEM-EDS の測定結果から，鉛の表面偏析度は $1.5 \times 10^{4}$ $\sim 4 \times 10^{4}$ 倍にも達することが判明した。このように高濃度 の鉛の表面偏析については, $\mathrm{Al}-100 \mathrm{ppm} \mathrm{Pb}$ 筞を $873 \mathrm{~K}$ の焼 なましで表面偏析が55\%にも達するとする Aloni ら6)のオー ジェ分析による報告がある。

一般に純アルミニウムの酸化皮膜は， $727 \mathrm{~K} て ゙$ 約 $36 \mathrm{ks}$ 以 上の焼なましでアモルファス相から結晶体（多分 $\gamma$ ーアル ナ）へと変化するとされている13)。しかし Fig. 9(d) 拈よび Fig. 10 (c)のSADP に示されたよらに, 酸化皮膜はアモルフ ァス相から構成されていた。現在のところ，このよらな高温 でアモルファス相を生成する原因は，酸化皮膜中に多量の鉛 を含有したためアモルファス相の結晶化温度が上昇したため と考えざるをえない。

さて，Fig. 9 扩よび Fig. 10に拈いて，酸化皮膜は，30〜 50 at \% もの鉛を含有しているにもかかわらず，鉛をほとん ど含有していないアルミニウム母相より明るく観察された。 これに関して，ミクロトームでカットした母相中に転位が多 数導入され集積していることを, 本実験で確認している。そ のため, 酸化皮膜が相対的に明るく観察されたと考学られる。

鉛の表面偏析に関する RBS 測定と TEM-EDS 分析の結果 を比べると, 深さ方向の鉛濃度分布の大まかな形状, たとえ ば鉛濃度が減少する深さについてはあまり大きくは違わない が，偏析鉛濃度の絶対值にかなりの違いが認められた。Fig. 3 の $813 \mathrm{~K}$ で $14.4 \mathrm{ks}$ 焼なまし材の RBS では約 0.2 at\%である が TEM-EDS 分析（Fig. 12）ではそれが30～50 at\%となっ た。さらに, Fig. 5 の $923 \mathrm{~K}$ で72 ks 焼なましの RBS は, 0.7 〜0.8 at\%に対し, Fig. 13の TEM-EDS では20〜 50 at\%とな った。これは, TEM-EDS 分析が $\phi 5 \mathrm{~nm}$ の領域の分析であ るのに対し, RBS 測定值は $\phi 2 \mathrm{~mm}$ の面積に括ける平均組成 である。酸化皮膜の厚さが均一でなく大きく異なるため, RBS 測定の際は, 鉛含有量の多い酸化皮膜と鉛が汇とんど ない母相の両方を一緒に測定している可能性が極めて高い。 そのために両方法での測定值に上記のような違いが現れたと 考えられる。

\footnotetext{
* 酸素濃度の定量值は高純度アルミナ粉末で確認した。
}
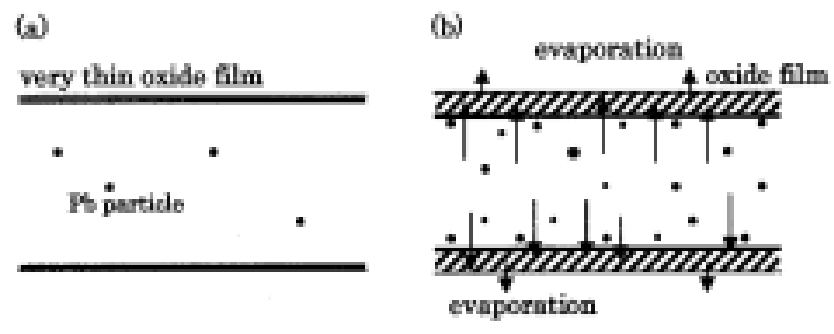

Fig. 14 Proposal of surface segregation processes of $\mathrm{Pb}$ in $\mathrm{Al}-\mathrm{Pb}$ foil during annealing treatment. (a) initial stage, (b) later stages (diffusion through aluminum to oxide film and evaporation of lead).

\section{3 表面偏析過程}

前報10) そ拈いて, 焼なましを施した䈃表面近傍のアルミニ ウム母相中にファセット界面を有する微小な $\mathrm{Pb}$ 粒子の生成 を TEM 観察で見出し報告した。さらに, 筞内部の中央部の サブグレイン粒界に沿ってファセット面を持たない鉛粒子を 見出し，焼なまし前にすでに鉛粒子が存在していたことも報 告した ${ }^{14)}$ 。

一般に, 表面偏析は粒界偏析に類似の現象として取り扱わ れてきた ${ }^{12)}$ 。とこでは, 不純物元素の粒界への拡散偏析によ って粒界ェネルギーの減少を引き起こすことが偏析の主駆動 力とするものである。しかし, Lea と Seah ${ }^{15}$ は, 表面偏析 速度は, バルク内の溶質元素の拡散速度以外に表面からの蒸 発速度も考慮し, その両者の差が表面偏析の速度とした。さ らにこの彼らの考光は, 鉄中すずの表面偏析実験データによ く一致するとしている。我々も, 加熱試料台を用いたその場 TEM 観察により, 昇温に伴って管中の鉛粒子が蒸発で消滅 することを報告した ${ }^{14)}$ 。また, Fig. 12执よび Fig. 13の鉛濃 度のプロファイルの比較から, 高温・長時間ではアルゴン気 流中に敃いても酸化皮膜表面から鉛が蒸発する傾向が見られ た。

本実験結果ならびに前報での結果10),14), さらに Lea ら ${ }^{15)}$ の考えに基づいて, 熱処理に伴うアルミニウム中鉛の表面偏 析過程は次のように考えることができる（Fig. 14）。まず， 熱処理前または熱処理直後の筞では, アルミニウム中に固溶 している鉛と箔内部の鉛粒子が存在して拉り, さらに䈋表面 は極薄い酸化皮膜で覆わ机ていであろら。次いで, 熱処理 中に，(1)アルミニウム中の固溶鉛は熱拡散による表面への 拡散，(2) アルミニウム表面では熱処理による酸化皮膜の成 長，（3）表面に拡散してきた鉛の酸化皮膜中への移行，(4) 酸 化皮膜中鉛のその表面からの蒸発，(5)これらと平行して拡 散中にアルミニウム中の欠陷部に鉛が析出してファセット面 を持つ微細な鉛粒子の形成, といら過程である。その内，(1) 〜(3)の過程は流とんど同時に進行するのではないかと考光ら れる。鉛の低濃度箔の場合は, Fig. 14中の初期段階に鉛粒 子が存在しないであろらとする点以外は, 上記と同じ表面偏 析過程が進行すると考光られる。な拈, 酸化皮膜中へ鉛が取 り込まれー移行する原因は, 今のところ $\mathrm{Al}_{2} \mathrm{O}_{3}-\mathrm{PbO}$ 系の状態 図 ${ }^{16)}$ に示されるように化合物形成に関係あると考兄られる。

\section{4. 結言}

(1) $\mathrm{Al}-13 \mathrm{ppm} \mathrm{Pb}$ 合金筞をアルゴン気流中, $673 \sim 923 \mathrm{~K}$, 1.8〜 72 ks の焼なましを施すと, 鉛は䇴表面近傍へ著しく偏 
析した。高温で長時間焼なましすれば，管表面への鉛の偏析 量は増大し，さらに馢表面からより深い位置まで偏析鉛は存 在した。 $\mathrm{Al}-0.13 \mathrm{ppm} \mathrm{Pb}$ 合金簿の焼なましに拮いても，高 濃度箔と同様な偏析現象を示した。

(2) $\mathrm{Al}-13 \mathrm{ppm} \mathrm{Pb}$ 合金䈃の断面 TEM 観察の結果, 焼な まし中にアルミニウム母相表面に酸化皮膜が形成されてい た。その酸化皮膜は本実験の最高温度 $(923 \mathrm{~K})$ でもアモル ファス相からなっていることが明らかになった。

(3) 偏析鉛の注之几ぞは酸化皮膜中に存在し, 酸化皮膜/ 母相界面には鉛の偏析はほとんど認められなかった。酸化皮 膜中の鉛濃度は場所によって異なったが，鉛の表面偏析は母 相初期濃度の $1.5 \times 10^{4} \sim 4 \times 10^{4}$ 倍にも達することが判明した。

（4）鉛の表面偏析量は，アルミニウム中の拡散による表面 偏析と酸化皮膜表面からの蒸発の差であらう。

\section{参 考 文 献}

1）福岡 潔：軽金属, 51 (2001), 370 .

2) K. Arai, T. Suzuki and T. Atsumi: J. Electrochem. Technol., 132 (1985), 1667.

3）後藤博己，坂田和幸，当摩 建：軽金属，42（1992）, 549 .
4) W. Lin, G. C. Tu, C. F. Lin and Y. M. Peng: Corros. Sci., 38 (1996), 889

5) 名取敏雄, 細田昌孝, 石井由美子: 電解蓄電器評論, 47 (1997), 48.

6) S. Aloni and M. Polak, Surf. Sci., 349 (1996), L123.

7) Z. Ashitaka, G. E. Thompson, P. Skeldon, G. C. Wood, H. Habazaki and K. Shimizu: J. Electrochem. Soc., 146 (1999), 1380, 147 (2000), 132.

8）藤井一男, 清水 遵: 電解蓄電器研究会資料, (1999. 12. 9), 1.

9）川井正彦，清水健一：表面技術第17回 ARS 予稿, (2000), 7.

10）椿野晴繁, 寺澤倫孝, 三田村徹, 野上敦司, 杉本公徳, 木野 村淳 : 軽金属, 51 (2001), 98 .

11) H. Tsubakino, A. Nogami and T. Yamanoi: Appl. Surf. Sci., 185 (2002), 298.

12) P. Wynblatt and R. C. Ku: Interfacial Segregation, Eds. by W. C. Johnson and J. M. Blakely, ASM, Ohio, (1979), 115.

13) M. J. Dignam, W. R. Fawcett and H. Böhni: J. Electrochem. Soc., 113 (1966), 656.

14）椿野晴繁, 野上敦司, 山/井智明 : 軽金属学会第101回秋期大 会講演概要, (2001), 295.

15） C. Lea and M. P. Seah: Phil. Mag., 35 (1977), 213.

16) E. M. Levin, C. R. Robbins and H. C. McMurdie: Phase Diagrams for Ceramists, Ed. by M. K. Reser, Am. Ceram. Soc., Ohio, (1969), 115. 